\title{
Inorganic phosphorus decrease after intravenous glucose tolerance test is associated with insulin resistance in dairy cows
}

\author{
Marko R. Cincović1*, Radojica Djokovićé, Branislava Belić1, \\ Aleksandar Potkonjak ${ }^{1}$, Bojan Toholj ${ }^{1}$, Nenad Stojanac ${ }^{1}$, \\ Ognjen Stevančević ${ }^{1}$, and Jože Starič $\check{c}^{3}$
}

\author{
${ }^{1}$ Department of Veterinary Medicine, Faculty of Agriculture, University of Novi Sad, Novi Sad, Serbia \\ ${ }^{2}$ Department of Animal Science, Faculty of Agronomy, University of Kragujevac, Čačak, Serbia \\ ${ }^{3}$ Section for diseases and health care of ruminants, Veterinary Faculty, University of Ljubljana, Slovenia
}

\section{CINCOVIĆ, M. R., R. DJOKOVIĆ, B. BELIĆ, A. POTKONJAK, B. TOHOLJ, N. STOJANAC, O. STEVANČEVIĆ, J. STARIČ: Inorganic phosphorus decrease after intravenous glucose tolerance test is associated with insulin resistance in dairy cows. Vet. arhiv 87, 409-418, 2017.}

\section{ABSTRACT}

Inorganic phosphorus $(\mathrm{Pi})$ concentration in blood decreases during an intravenous glucose tolerance test (IVGTT) due to the increase in the level of insulin and glucose. The objective of the present study was to determine the relationship between the intensity of Pi decrease with a dynamic change of insulin and glucose during IVGTT (AUC - total area under curve, AUC increment - area under curve from start of IVGTT to time of maximal response and glucose CR-clearance rate), as well as RQUICKI (Revised Quantitative Insulin Sensitivity Check Index) and RQUICKI-BHB (RQUICKI with beta hydroxybutyrate in formula) indexes of insulin resistance. The experiment included healthy and ketotic cows. Metabolic changes in ketotic cattle are similar to healthy cows in early lactation; ketosis represents impaired metabolic adaptation with higher insulin resistance. In both groups we found increases in insulin and glucose concentrations and Pi AUC during IVGTT, but these changes were less pronounced in the ketotic group. Ketotic cows showed a lower RQUICKI and RQUICKI-BHB index which indicates a higher level of insulin resistance. Pi AUC was in positive correlation with glucose response (glucose AUC), and this correlation is controlled with insulin response to glucose (insulin AUC). Pi AUC also showed a positive correlation with maximal glucose and insulin concentration during IVGTT, AUC and AUC increment for glucose and insulin, and glucose CR. These correlations were controlled by RQUICKI and RQUICKI-BHB indexes. The Pi decrease after the intravenous glucose tolerance test in dairy cows is associated with all aspects of insulin resistance, that include the insulin response to glucose (insulin AUC) and tissue response to insulin (RQUICKI and RQUICKI-BHB).

Key words: phosphorus, insulin resistance, cow, ketosis, RQUICKI

\footnotetext{
*Corresponding author:

Asist. Prof. Dr. Marko R. Cincović, Department of Veterinary Medicine, Faculty of Agriculture, University of Novi Sad, Trg D. Obradovića 8, 21000, Novi Sad, Serbia, Phone: +381 21485 3516; E-mail: mcincovic@gmail.com
} 
M. R. Cincović et al.: Inorganic phosphorus decrease is associated with insulin resistance in dairy cows

\section{Introduction}

Phosphorus in many ways shows correlations with values of glucose and insulin. Insulin promotes the transport of both glucose and phosphate into the skeletal muscle and liver, which leads to only a slight decrease in serum Pi levels (LIAMIS et al., 2010). Administration of glucose to cattle causes decreased blood concentrations of phosphorus, attributable to high levels of insulin (GRÜNBERG et al., 2006). In humans it was shown that glucose disposal rate (as a measurement of the efficiency of insulin action) was higher after phosphate infusion during euglycaemic clamp studies (NOWICKI et al., 1996). Phosphate depletion is associated with insulin resistance in the peripheral tissue and with glucose intolerance (ZHOU et al., 1991). Some results show that cows in ketosis have lower levels of phosphorus, glucose and insulin (DJOKOVIĆ et al., 2007).

Cows in early lactation show a predisposition for developing metabolic diseases. Ketosis is one of the most common metabolic disorders. Negative energy balance is a crucial factor in developing ketosis. Greater lipolysis in tissues takes place in order to compensate for the negative energy balance, but insulin resistance is also needed. Insulin resistance in ketosis is characterized by lower concentrations of insulin and glucose, reduced responsiveness of insulin to glucose, greater lipolysis in peripheral tissues, ketone body production and lower RQUICKI index values (HAYIRLI, 2006; XU et al., 2014).

Previously there have been no data on the relationship between Pi and insulin resistance in cows. The aim of the present study was to estimate the relationship between basal levels and the dynamic change during IVGTT (intravenous glucose tolerance test) of blood glucose, insulin and $\mathrm{Pi}$, and their relationship to indexes of insulin resistance (Revised Quantitative Insulin Sensitivity Check Index RQUICKI and RQUICKI with beta hydroxybutyrate in formula - RQUICKI-BHB,).

\section{Materials and methods}

Cows and management - the experiment included 15 Holstein dairy cows: eight healthy and seven cows with ketosis in the earliest stage of lactation (7-14 days postpartum). The diagnosis of ketosis was based on BHB concentration in blood at level $>1.4$ $\mathrm{mmol} / \mathrm{L}$ (OETZEL, 2004) and ketone bodies in the urine-qualitative analysis. The cows were of similar body mass $(560-580 \mathrm{~kg})$, on average in their $3^{\text {rd }}$ lactation with a mean milk yield of $7850 \pm 450.5 \mathrm{~L}$ (calculated over 305 days) in the previous lactation. The total mix ration (TMR) was formulated for animals in early lactation. Early lactation cows were fed a TMR consisting of $7 \mathrm{~kg}$ lucerne hay, $20 \mathrm{~kg}$ maize silage (30\% Dry Matter, DM), $5 \mathrm{~kg}$ concentrate ( $18 \%$ crude proteins, $\mathrm{CP}$ ). The chemical characteristics of TMR were: 87.15 MJ NEL (net energy lactation); crude protein $13.58 \%$ of DM; rumen undegradable protein $35.91 \%$ of crude protein; fat $3.09 \%$ DM, fibre $23.26 \%$ DM. 
Intravenous glucose tolerance test (IVGTT) and calculation - The test was carried out in the morning at $09-10 \mathrm{~h}$ about $3 \mathrm{~h}$ after feeding. A solution of glucose $(500 \mathrm{ml}$ of $50 \%)$ was administered intravenously via the jugular vein over 5 minutes. Blood samples were taken from the opposite jugular vein before (0, T0) and 5 (T5), 10 (T10), 30 (T30), and 60 (T60) minutes after the injection. Blood samples were collected into vacuum tubes for serum separation and fluoride-containing tubes (glucose determination). Fluoridecontaining tubes were placed on ice and immediately transported to the laboratory, where they were centrifuged (1500g, 10 minutes), and blood plasma was carefully harvested and stored at $-20{ }^{\circ} \mathrm{C}$ until analysis.

The following values were determined during IVGTT: AUC (total area under curve) for insulin and glucose (trapezoidal method, 0-60 min, baseline at level Y = 0) and AUC increment (0-5 min for glucose, 0-10 min for insulin), glucose clearance $(\mathrm{CR}=100 \times \mathrm{k}$; $k$ is the regression coefficient); Pi AUC (trapezoidal method, baseline passes through minimal Pi concentration at T60). Indexes of insulin resistance were calculated by the standard formula: RQUICKI = 1/[log (conc.T0 glucose $\mathrm{mg} / \mathrm{dL})+\log$ (conc.T0 insulin mmol/1)+log (conc.T0 NEFA mmol/l)]; RQUICKI-BHB = 1/[log (conc.T0 glucose mg/ $\mathrm{dL})+\log ($ conc.T0 insulin $\mu \mathrm{U} / \mathrm{mL})+\log ($ conc.T0 NEFA mmol/l) $+\log ($ conc.T0 BHB $\mathrm{mmol} / \mathrm{l})]$.

Laboratory assay - Blood insulin was determined using a standard ELISA kit (Cusabio, $\mathrm{CH}$ ) on a Rayto reader. Blood glucose, Pi, NEFA (non-esterified fatty acid) and BHB (beta hydroxybutyrate) were determined spectrophotometrically using a standard kit (Randox, UK) and a Rayto spectrophotometer.

Statistics - The time influence after IVGTT to concentration of glucose, insulin and Pi was analyzed by the ANOVA-procedure with post hoc LSD test. Values (basal concentration and dynamic change of insulin, glucose and Pi, AUC and AUC increment, CR, RQUICKI and RQUICKI-BHB) for cows in different groups were compared by performing Student's $t$-tests. Pearson correlation coefficients were calculated for raw or log-transformed values in the total group (healthy and ketotic). A partial correlation was determined between: a) values of Pi AUC and glucose, when insulin AUC was excluded as a control factor, b) values of $\mathrm{Pi}$, insulin and glucose during IVGTT after excluding RQUICKI and RQUICKI-BHB indexes as control factors. Graphic presentation of the partial correlation between $\mathrm{A}$ and $\mathrm{B}$ variables, when $\mathrm{C}$ is excluded as control, was performed by showing correlations between residuals that were formed in correlations $\mathrm{A}: \mathrm{C}$ and B:C. The calculations were performed by Statgraphic Centurion (Statpoint Technologies Inc., Warrenton, USA) and Microsoft Excel software. 
M. R. Cincović et al.: Inorganic phosphorus decrease is associated with insulin resistance in dairy cows

\section{Results}

Glucose application during IVGTT caused major temporal changes in insulin concentration, glucose and Pi. Glucose maximum concentration was noted at T5, but maximum insulin concentration was noted at T10. Phosphorus concentration decreased from T0 to T60.

Table 1. Insulin, glucose, Pi, RQUICKI and RQUICKI-BHB in healthy and ketotic cows

\begin{tabular}{|l|c|c|c|}
\hline Parameters* & Healthy $(\mathrm{n}=8)$ & Ketotic $(\mathrm{n}=7)$ & $\mathrm{P}$ \\
\hline Insulin T0 $(\mathrm{pmol} / \mathrm{L})$ & $195.3 \pm 15.8$ & $210.9 \pm 19.4$ & $<0.1$ \\
\hline Insulin T5 $(\mathrm{pmol} / \mathrm{L})$ & $320.6 \pm 35.1$ & $250.5 \pm 36.2$ & $<0.01$ \\
\hline Insulin T10 $(\mathrm{pmol} / \mathrm{L})$ & $889.4 \pm 29.8$ & $350.4 \pm 33.7$ & $<0.01$ \\
\hline Insulin T30 $(\mathrm{pmol} / \mathrm{L})$ & $250.2 \pm 19.1$ & $230.7 \pm 21.6$ & $\mathrm{NS}$ \\
\hline Insulin T60 $(\mathrm{pmol} / \mathrm{L})$ & $200.5 \pm 12.3$ & $215.2 \pm 16.4$ & $\mathrm{NS}$ \\
\hline Insulin AUC $(\mathrm{pmol} / \mathrm{L} \times \mathrm{h})$ & $22450.5 \pm 2150.3$ & $15125.2 \pm 1649.1$ & $<0.01$ \\
\hline Insulin AUC increment $(\mathrm{pmol} / \mathrm{L} \times \mathrm{h})$ & $15732.1 \pm 1596.5$ & $8910.2 \pm 707.7$ & $<0.01$ \\
\hline Glucose T0 $(\mathrm{mmol} / \mathrm{L})$ & $3.3 \pm 0.8$ & $2.5 \pm 0.9$ & $<0.05$ \\
\hline Glucose T5 $(\mathrm{mmol} / \mathrm{L})$ & $8.5 \pm 1.2$ & $3.9 \pm 0.9$ & $<0.01$ \\
\hline Glucose T10 $(\mathrm{mmol} / \mathrm{L})$ & $5.9 \pm 1.3$ & $3.1 \pm 1.1$ & $<0.01$ \\
\hline Glucose T30 $(\mathrm{mmol} / \mathrm{L})$ & $4.7 \pm 1.1$ & $2.8 \pm 0.8$ & $<0.01$ \\
\hline Glucose T60 $(\mathrm{mmol} / \mathrm{L})$ & $3.4 \pm 0.9$ & $2.2 \pm 0.9$ & $<0.1$ \\
\hline Glucose AUC $(\mathrm{mmol} / \mathrm{L})$ & $293.8 \pm 33.5$ & $165.5 \pm 20.1$ & $<0.01$ \\
\hline Glucose AUC increment $(\mathrm{mmol} / \mathrm{L} \times \mathrm{h})$ & $65.9 \pm 7.8$ & $40.3 \pm 3.9$ & $<0.01$ \\
\hline Glucose CR $(\% \mathrm{~min})$ & $7.8 \pm 1.8$ & $2.3 \pm 0.6$ & $<0.01$ \\
\hline Pi T0 $(\mathrm{mmol} / \mathrm{L})$ & $1.92 \pm 0.19$ & $1.71 \pm 0.18$ & $<0.05$ \\
\hline Pi T5 (mmol/L) & $1.69 \pm 0.20$ & $1.60 \pm 0.15$ & $\mathrm{NS}$ \\
\hline Pi T10 $(\mathrm{mmol} / \mathrm{L})$ & $1.59 \pm 0.16$ & $1.55 \pm 0.17$ & $\mathrm{NS}$ \\
\hline Pi T30 $(\mathrm{mmol} / \mathrm{L})$ & $1.55 \pm 0.21$ & $1.54 \pm 0.19$ & $\mathrm{NS}$ \\
\hline Pi T60 $(\mathrm{mmol} / \mathrm{L})$ & $1.51 \pm 0.15$ & $1.49 \pm 0.14$ & $\mathrm{NS}$ \\
\hline Pi AUC $(\mathrm{mmol} / \mathrm{L} \times \mathrm{h})$ & $4.48 \pm 0.62$ & $2.15 \pm 0.57$ & $<0.01$ \\
\hline Pi CR $(\% \mathrm{~min})$ & $0.51 \pm 0.1$ & $0.22 \pm 0.1$ & $<0.01$ \\
\hline RQUICKI & $0.37 \pm 0.05$ & $0.34 \pm 0.04$ & $<0.05$ \\
\hline RQUICKI-BHB & $0.38 \pm 0.04$ & $0.31 \pm 0.03$ & $<0.01$ \\
\hline
\end{tabular}

*T0, T5, T10, T30, T60- time of blood sample after glucose administration in IVGTT; AUC-total area under curve during IVGTT; AUC incr - AUC from start of IVGTT to maximal concentration of glucose (0-5 min) and insulin (0-10 min); CR\% - clearance rate \%min; RQUICKI- Revised Quantitative Insulin Sensitivity Check Index, RQUICKI-BHB- RQUICKI with BHB in formula. 
Cows in ketosis were compared to the healthy group and showed lowered concentrations of glucose, insulin and phosphorus; decreased glucose (glucose AUC), insulin (insulin AUC) and Pi responsiveness during IVGTT. Insulin resistance was more pronounced in ketotic cows with reduced RQUICKI and RQUICKI-BHB indexes values (Table 1 and Fig. 1).

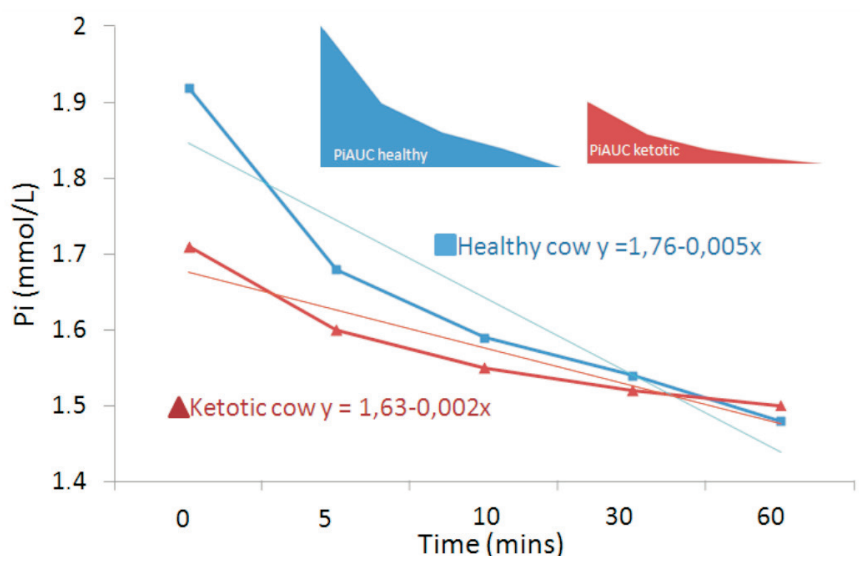

Fig. 1. Pi response in healthy and ketotic cows during IVGTT, Pi - inorganic phosphorus, AUC total area under curve during intravenous glucose tolerance test

Correlations of glucose, phosphorus and insulin concentrations were not established during T0-T60. However, the dynamic response of Pi (Pi AUC) and glucose (glucose AUC) showed a positive correlation. The dynamic response to insulin (insulin AUC) during IVGTT led to the previous correlation, because its exclusion causes loss of the Pi AUC: glucose AUC correlation (Fig. 2a-b).

Inorganic phosphorus $\mathrm{CR}$ and $\mathrm{Pi}$ AUC showed a positive correlation with the maximum glucose concentration (T5) and insulin (T0). A positive correlation was also determined between insulin response and glucose in sight of AUC increment. The higher clearance of glucose correlated with the higher clearance of Pi. All these linear relations were controlled by the RQUICKI and RQUICKI-BHB insulin resistance indexes because their absence may cause a lower partial correlation that is so strong that the linear correlation cannot be determined (Table 2). 
M. R. Cincović et al.: Inorganic phosphorus decrease is associated with insulin resistance in dairy cows

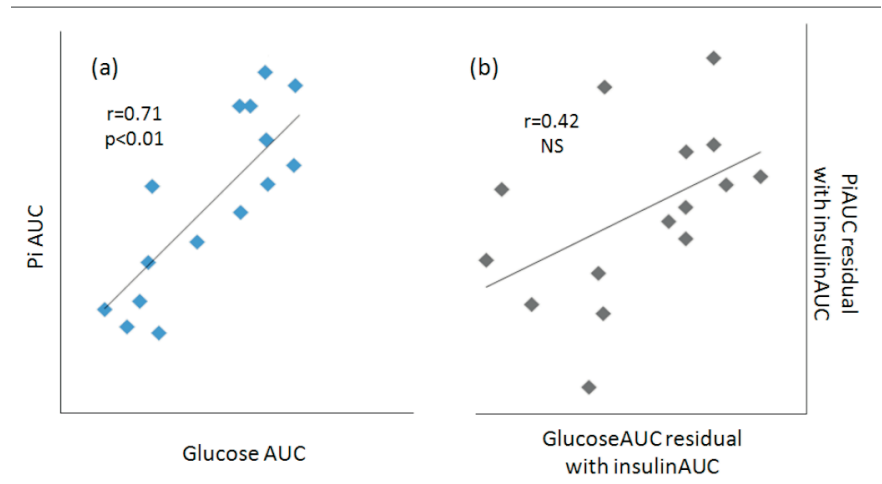

Fig. 2. a-b. Regression line between Pi AUC and glucose AUC (a) and their relationship after exclusion of insulin AUC as control (b); Pi AUC - inorganic phosphorus total area under curve, glucose AUC - glucose total area under curve during intravenous glucose tolerance test, rcorrelation coefficient

Table 2. Partial correlation between PiAUC and PiCR with insulin or glucose parameters during IVGTT after exclusion of RQUICKI and RQUICKI-BHB as control of correlation

\begin{tabular}{|l|c|c|c|}
\hline Parameters $\dagger$ & $\begin{array}{c}\text { Original correlation } \\
\text { before exclusion }\end{array}$ & $\begin{array}{c}\text { RQUICKI } \\
\text { exclusion }\end{array}$ & $\begin{array}{c}\text { RQUICKI-BHB } \\
\text { exclusion }\end{array}$ \\
\hline PiAUC: Insul T10 & $0.76^{* *}$ & $0.42^{\Delta}$ & $0.46^{\Delta}$ \\
\hline PiAUC: InsulAUCincr & $0.71^{* *}$ & $0.37^{\Delta}$ & $0.39^{\Delta}$ \\
\hline PiAUC: GluT5 & $0.69^{* *}$ & $0.42^{\Delta}$ & $0.27^{\Delta}$ \\
\hline PiAUC: GluAUC & $0.71^{* *}$ & $0.36^{\Delta}$ & $0.35^{\Delta}$ \\
\hline PiAUC: GluAUCincr & $0.84^{* *}$ & $0.38^{\Delta}$ & $0.26^{\Delta}$ \\
\hline PiAUC: GluCR\% & $0.74^{* *}$ & $0.47^{\Delta}$ & $0.41^{\Delta}$ \\
\hline PiCR: Insul T10 & $0.68^{* *}$ & $0.49^{\Delta}$ & $0.37^{\Delta}$ \\
\hline PiCR: InsulAUCincr & $0.65^{* *}$ & $0.4^{\Delta}$ & $0.44^{\Delta}$ \\
\hline PiCR: GluT5 & $0.63^{* *}$ & $0.32^{\Delta}$ & $0.33^{\Delta}$ \\
\hline PiCR: GluAUC & $0.56^{*}$ & $0.38^{\Delta}$ & $0.42^{\Delta}$ \\
\hline PiCR: GluAUCincr & $0.65^{* *}$ & $0.31^{\Delta}$ & $0.32^{\Delta}$ \\
\hline PiCR: GluCR\% & $0.7^{* *}$ & $0.39^{\Delta}$ & $0.46^{\Delta}$ \\
\hline
\end{tabular}

$\Delta$ - absence of linear correlation after exclusion of control factors; $\dagger$ - Pi-inorganic phosphor; insul-insulin, AUC-total area under curve during IVGTT; AUC incr - AUC from start of IVGTT to maximal concentration of glucose (0-5 $\mathrm{min})$ and insulin (0-10 $\mathrm{min})$; CR\% - clearance rate \% $\mathrm{min}$; T5,T10-time of blood sample after glucose administration in IVGTT; RQUICKI- Revised Quantitative Insulin Sensitivity Check Index, RQUICKIBHB- RQUICKI with BHB in formula. 
M. R. Cincović et al.: Inorganic phosphorus decrease is associated with insulin resistance in dairy cows

\section{Discussion}

Dairy cows in early lactation show a negative energy balance caused by insufficient feed intake for milk production. Major metabolic adaptations are needed in order to sustain the nutrient balance for milk production in dairy cows. Ketosis is a disorder which occurs in dairy cows that cannot adapt to metabolic challenges in this period (SUNDRUM, 2015). This disorder is characterized by insulin resistance, the reduced response of insulin to glucose, lower levels of glucose and lowered glucose clearance during IVGTT, greater lipid mobilization and synthesis of ketone bodies (WILCOX, 2005; DE KOSTER and OPSOMER, 2013). This study was performed in ketotic and healthy cows in early lactation, in other words in one group of cows that were well adapted to metabolic changes and a group of unadapted cows. The pathophysiological changes in early lactation allow use of this model to examine the influence of insulin resistance on Pi response during IVGTT. In addition, declining levels of blood phosphorus are a consequence of transfer of extracellular phosphorus into the intracellular compartment, higher concentrations of urine phosphorus and reduced absorption of dietary phosphorus. The first mechanism is short-termed, but the other two mechanisms are longer lived and therefore contribute more to the problem (MOE, 2008). Cows in early lactation have reduced feed intake, which is one of the main causes and symptoms of ketosis (OETZEL, 2007) and this could be related to lower levels of Pi. Decreasing blood $\mathrm{pH}$ values in ketosis may also have a part in reduced Pi level (LIAMIS et al., 2010). On the other hand, it was determined that hypophosphatemia can be related to reduced insulin production and insulin resistance occurrence (ZHOU et al., 1991), which are main characteristics of insulin resistance in ketosis.

Glucose application can cause $\mathrm{Pi}$ concentrations to decrease during IVGTT (GRÜNBERG et al., 2006), which was also established in this study. Clearance of Pi (PiCR) and intensity of declining Pi values (PiAUC) have a positive correlation with glucose, and the correlation was controlled by insulin response, which is the main innovation of this study. In addition, correlations between Pi, glucose and insulin during IVGTT were determined by the insulin resistance RQUICKI and RQUICKI-BHB indexes. Correlations of $\mathrm{Pi}$ and insulin resistance were shown in that way.

Cows that showed more intensive glucose and insulin response during IVGTT also had a greater decrease in $\mathrm{Pi}$ concentration and higher values on the insulin resistance indexes (they are less insulin resistant). Although more dramatic increases in glycaemia during IVGTT mean higher insulin resistance, because more insulin is needed in order to neutralize glucose, it has to be considered that cows are polygastric (they have to produce much of the glucose by gluconeogenesis) and a negative energy balance occurs. So, higher glycaemia and higher values of insulin during IVGTT are signs of a favourable energy balance and the better adaptation of cows (TERAO et al., 2010). 
It is well known that insulin application in humans with diabetes can cause mild hypophosphatemia (LIAMIS et al., 2010). Cows that have expressed reduced insulin response during IVGTT also have expressed reduced clearance of Pi. This confirms the significant role of insulin in the regulation of $\mathrm{Pi}$ concentrations. The low secretory responses of insulin in ketotic cows are therefore probably a result of a pancreas with a low secretory capacity for insulin, developed during the days or weeks of hypoglycemia, which regularly accompanies severe ketosis. The results of this study show the preserved function (relative insufficiency) of the beta cells of the endocrine pancreas of ketotic cows (max conc. of insulin - T0 conc. of insulin / max. conc. of glucose - Ti0 conc. of glucose was $143.7 \mathrm{pmol} / \mathrm{L}$ of insulin per $1 \mathrm{mmol} / \mathrm{L}$ of glucose in heathy cow vs. $107.14 \mathrm{pmol} / \mathrm{L}$ of insulin per $1 \mathrm{mmol} / \mathrm{L}$ of glucose in ketotic cow). Other authors have reported similar results (SAKAI et al., 1993; SAKAI et al.1996; HOLTENIUS et al., 2003; DJOKOVIĆ et al., 2009). All of this shows that Pi response depends on insulin response to glucose, that is the presence of insulin resistance.

RQUICKI and RQUICKI-BHB are indicators of insulin resistance in cows. The values of these indexes depend on NEFA and BHB values (CINCOVIĆ et al., 2014), because increases in NEFA and BHB cause a reduction in the values of these indexes, indicating that the cows are more insulin resistant. During early lactation, a negative energy balance, ketosis and greater concentrations of NEFA and BHB in the blood of cows are noted (OETZEL, 2007; ŠAMANC et al., 2015; DJOKOVIĆ et al., 2015). Higher values of NEFA and $\mathrm{BHB}$ in the blood can cause insulin resistance by affecting pancreatic islands that secrete less insulin, as well as the fact that they negatively affect insulin receptors in peripheral tissue (HAYIRLI, 2006). This may serve as an explanation of our results which show that the correlation between Pi response and insulin and glucose response during IVGTT depends on the RQUICKI and RQUICKI-BHB insulin resistance indexes.

In conclusion, decreases in Pi concentrations during IVGTT depend on the severity of insulin resistance, including insulin response to glucose, and the response of peripheral tissues to insulin.

\section{Acknowledgements}

This study was financially supported by the Ministry of Education and Science, the Republic of Serbia, Projects TR31062 and Bilateral project Srbija-Slovenia Laboratorijski pokazatelji metaboličkog statusa krava u ranoj laktaciji. The authors would like thank Prof. Meera Heller for critical reading and grammatical corrections.

\section{References}

CINCOVIĆ, M. R., B. BELIĆ, R. ĐOKOVIĆ, B. TOHOLJ, T. HRISTOVSKA, B. DELIĆ, M. DOŠENOVIĆ (2014): Insulin resistance in cow during dry period and early lactation. Contemp. Agric., 63 , 98-105. 
M. R. Cincović et al.: Inorganic phosphorus decrease is associated with insulin resistance in dairy cows

DE KOSTER, J. D., G. OPSOMER (2013): Insulin resistance in dairy cows. Vet. Clin. North Am. Food Anim. Pract. 29, 299-322.

DJOKOVIĆ, R., M. CINCOVIĆ, B. BELIĆ, B. TOHOLJ, I. DAVIDOV, T. HRISTOVSKA (2015): Relationship between blood metabolic hormones, metabolites and energy balance in Simmental dairy cows during peripartal period and lactation. Pak. Vet. J. 35, 163-167.

DJOKOVIĆ, R., H. ŠAMANC, Z. ILIĆ, V. KURĆUBIĆ (2009): Changes in blood values of glucose, insulin and inorganic phosphorus in healthy and ketotic dairy cows after intravenous infusion of glucose solution. Acta Vet. Brno 78, 449-453.

DJOKOVIĆ, R., H. ŠAMANC, Z. NIKOLIĆ, S. BOŠKOVIĆ-BOGOSAVLJEVIĆ (2007): Changes in blood values of glucose, insulin and inorganic phosphorus in healthy and ketotic dairy cows after intravenous infusion of propionate solution. Acta Vet. Brno 76, 533-539.

GRÜNBERG, W., D. E. MORIN, J. K. DRACKLEY, P. D. CONSTABLE (2006): Effect of rapid intravenous administration of $50 \%$ dextrose solution on phosphorus homeostasis in postparturient cows. J. Vet. Intern. Med. 20, 1471-1478.

HAYIRLI, A. (2006): The role of exogenous insulin in the complex of hepatic lipidosis and ketosis associated with insulin resistance phenomenon in postpartum dairy cattle. Vet. Res. Comm. 2006, 749-774.

HOLTENIUS, K., S. AGENAS, C. DELAVAUD, Y. CHILliARD (2003): Effects of feeding intensity during the dry period. 2. Metabolic and hormonal responses. J. Dairy Sci. 86, 883891.

LIAMIS, G., H. J. MILIONIS, M. ELISAF (2010): Medication-induced hypophosphatemia: a review. Q. J. Med. 103, 449-459.

MOE, S. M. (2008): Disorders involving calcium, phosphorus, and magnesium. Prim. Care 35, 215-37, v-vi.

NOWICKI, M., D. FLISER, P. FODE, E. RITZ (1996): Changes in plasma phosphate levels influence insulin sensitivity under euglycemic conditions. J. Clin. Endocrinol. Metab. 81, 156159.

OETZEL, G. R (2004): Monitoring and testing dairy herds for metabolic disease. Vet. Clin. North Am. Food Anim. Pract. 20, 651-674.

OETZEL, G. R. (2007): Herd-Level Ketosis - Diagnosis and Risk Factors. Preconference Seminar 7C: Dairy Herd Problem Investigation Strategies: Transition Cow Troubleshooting. pp. 67-91.

SAKAI, T., T. HAMAKAWA, M. HAMAKAWA, K. OGURA, S. KUBO (1993): Therapeutic effects of simultaneous use of glucose and insulin in ketotic cows. J. Dairy Sci. 76, 109-114.

SAKAI, T., HAMAKAWA, M., KUBO, S. (1996): Glucose and Xylitol tolerance test for ketotic and healthy cows. J. Dairy Sci. 79, 372-377.

SUNDRUM, A. (2015): Metabolic disorders in the transition period indicate that the dairy cows' ability to adapt is overstressed. Animals 5, 978-1020. 
M. R. Cincović et al.: Inorganic phosphorus decrease is associated with insulin resistance in dairy cows

ŠAMANC, H., D. GVOZDIĆ, N. FRATRIĆ, D. KIROVSKI, R. DJOKOVIĆ, Z. SLADOJEVIĆ, M. CINCOVIĆ (2015): Body condition score loss, hepatic lipidosis and selected blood metabolites in Holstein cows during transition period. Anim. Sci. Pap. Rep. 33, 35-47.

TERAO, H., M. FUJITA, A. TSUMAGARI, T. SUGINO, T. BUNGO (2010): Insulin dynamics in transition dairy cows as revealed by intravenous glucose tolerance testing. J. Anim. Vet. Adv. 9, 2333-2337.

WILCOX, G.(2005): Insulin and insulin resistance. Clin. Biochem. Rev. 26, 19-39.

XU, C., S. SHU, C. XIA, B. WANG, H.Y.ZHANG, B. JUN (2014): Investigation on the relationship of insulin resistance and ketosis in dairy cows. J. Vet. Sci. Technol. 5, 162. doi:10.4172/21577579.1000162.

ZHOU, X. J., G. Z. FADDA, A. F. PERNA, S. G. MASSRY (1991): Phosphate depletion impairs insulin secretion by pancreatic islets. Kidney Int. 39, 120-128.

Received: 4 February 2016

Accepted: 10 February 2017

\section{CINCOVIĆ, M. R., R. DJOKOVIĆ, B. BELIĆ, A. POTKONJAK, B. TOHOLJ, N. STOJANAC, O. STEVANČEVIĆ, J. STARIČ: Opadanje neorganskog fosfora tijekom intravenskog testa tolerancije na glukozu povezano je $s$ inzulinskom rezistencijom u mliječnih krava. Vet. arhiv 87, 409-418, 2017.}

\section{SAŽETAK}

Koncentracija neorganskog fosfora (engl. inorganic phosphorus, Pi) u krvi opada tijekom intravenskog testa tolerancije na glukozu (engl. intravenous glucose tolerance test, IVGTT) zbog porasta koncentracije inzulina i glukoze. Cilj je ovog istraživanja bio da se utvrdi veza između opadanja vrijednosti Pi s dinamskim promjenama vrijednosti inzulina i glukoze tijekom IVGTT (AUC - ukupna površina ispod krivulje, AUC increment - površina ispod krivulje od početka IVGTT do trenutka kada se postiže maksimalni odgovor i CR-klirens glukoze), kao i vrijednostima indeksa inzulinske rezistencije RQUICKI (eng., Revised Quantitative Insulin Sensitivity Check Index) i RQUICKI-BHB (RQUICKI preinačen s vrijednošću beta-hidroksibutirata). U pokus su bile uključene zdrave i ketozne krave. Metaboličke promjene kod ketoznih krava slične su promjenama kod zdravih krava u ranoj laktaciji, s tim što ketoza nastaje kao znak loše metaboličke adaptacije s inzulinskom rezistencijom. U obje skupine ustanovljen je porast inzulina i glukoze i Pi AUC tijekom IVGTT, ali su ove promjene manje izražene kod ketoznih krava. Ketozne su krave imale nižu vrijednost RQUICKI i RQUICKI-BHB indeksa, što upućuje na veću razinu inzulinske rezistencije. Pi AUC je bio u pozitivnoj korelaciji s odgovorom glukoze (AUC glukoze), a ova je korelacija bila pod kontrolom odgovora inzulina na glukozu (AUC inzulina). Pi AUC pozitivno korelira s maksimalnom koncentracijom glukoze i inzulina postignutom tijekom IVGTT, AUC i AUC porasta za glukozu i inzulin i CR glukoze. Sve su navedene korelacije kontrolirane vrijednostima RQUICKI i RQUICKI-BHB indeksa. Opadanje Pi tijekom intravenskog testa tolerancije na glukozu kod mliječnih krava povezana je sa svim aspektima inzulinske rezistencije, što je odgovor inzulina na glukozu (AUC inzulina) i odgovor tkiva na inzulin (RQUICKI i RQUICKI-BHB).

Ključne riječi: fosfor, inzulinska rezistencija, krave, ketoza, RQUICKI 